\title{
The Application of Rice Hull Mulch and Potassium Nitrate on Growth and Yield of Kailan (Brassica oleraceae var. Long Leaf)
}

\author{
Sri Ramadiana \\ Program Study of Agrotechnology, Faculty of Agriculture, University of Lampung, \\ Jl. Sumantri Brojonegoro No. 1, Bandarlampung 35145, Indonesia \\ email: sriramadiana@yahoo.com
}

Received 2 July 2010 / accepted 21 March 2011

\begin{abstract}
Potassium $(\mathrm{K})$ is absorbed by plants in larger amounts than any other mineral element except $\mathrm{N}$ to optimalize plant growth. Mulches may be influenced an available $\mathrm{K}$ at vegetative growth phase of plant. The research was conducted in Simpang Kanan Village, Gisting, Tanggamus Lampung Province. The objectives of this research were to study the application of $\mathrm{KNO}_{3}$ and rice hull mulch on growth and yield of kailan. Fields experiments were arranged by a factorial in a completely randomized block design with 10 treatments and 3 replications. A first factor was (1) dosages of $\mathrm{KNO}_{3}\left(150,175,200,225\right.$, and $250 \mathrm{~kg} \mathrm{ha}^{-1}$ ) and the second factor was mulch of the rice hull (with and without the rice hull). The results showed that the application of the rice hull did not significantly affected the yield of kailan, however the application of $\mathrm{KNO}_{3}$ till $250 \mathrm{~kg} \mathrm{ha}^{-1}$ increased the level of greenness up to $6.10 \%$ and the wide of leaf up to $18,57 \%$. In addition, the present of potassium fertilizer suspended with the rice hull significantly affected the width of kalian leaf.
\end{abstract}

Keywords: Kailan, mulch, potassium nitrate, rice hull

\section{INTRODUCTION}

Kailan, Chinese broccoli, (Brassica oleraceae var. Long Leaf) is a vegetables with a high nutrition and vitamins content. This crop belongs to Brassicaeae family and is one of the leave vegetables founded by the community (Yamaguchi 1983). As kailan has a big potential for human consumption, effort should be made through precise cultural technique to gain optimal production. The purposed cultural technique is the application of optimum fertilizers and mulching.

Generally, the growth and yield of crops are depended on the optimal requirement of nutrient element for preparing the soil as a growing medium. Fertilizing will be done whenever the soil could not able to prepare nutrient elements in an adequate quantity for the plants. Potassium is one of the important macro elements for plant growth. Oldham (2008) and Aljabri (2007) stated that the dynamic of $\mathrm{K}$-forms in the soil comprises of mineral fixed K, un-exchangeable K (90-98\%

J Trop Soils, Vol. 16, No. 2, 2011: 145-150 ISSN 0852-257X of total mineral $\mathrm{K}$ ), exchangeable $\mathrm{K}$ (1-10\% of total $\mathrm{K}$ ) and dissolved $\mathrm{K}(1-2 \%$ of total $\mathrm{K})$.

The potassium mineral absorbed by the plants from the soil in the form of $\mathrm{K}^{+}$cation. According to Summers (2001), the K- nutrient is easily lost from the soil due to washing (being washed) or being absorbed by the plants, especially in areas of high rainfall (> $750 \mathrm{~mm})$ and sandy soil.

Indonesia is a moist tropical area with high soil erosion level and nutrients leaching. These are the results of high solar energy and high rainfall all the year long (Al Jabri 2007; Mapegau 2001). Jin (1997) added that in fact K-nutrient was lost more or transported by the soil through rain water or erosion. Furthermore, Nursyamsi et al.(2006) stated that the scarcity is an important problem and quite often happen on tropical soils (Indonesia). This is due to the poor condition in $\mathrm{K}$, the ease of $\mathrm{K}$-nutrient washed as the high precipitation of the tropical soil and the low CEC.

According to Labosky and Bundy (2005), the use of potassium fertilizer is less attention compared to the use of nitrogen and phosphorus fertilizers. Actually, the role of $\mathrm{K}$ is a quite important. As one of macro elements, it has an important role for the plants. Furthermore, according to Havlin et al. (2005), K plays a role as catalyst agent in the 
metabolism, such as (1) to increase the enzyme activity, (2) to reduce transpiration water loss through stomata arrangement, (3) to increase ATP production, (4) to help or improve assimilate transportation and (5) to increase $\mathrm{N}$ - absorption and protein synthesis. In addition, $\mathrm{K}$ supply also has the role as stabilizing affected on N, P, and other elements (Mallarino and Havlovic 2008; Nursyamsi et al. 2006).

According to Erwiyono et al. (2006), utilizing nitrogen element bound $\mathrm{K}$ in the form of nitrate $\left(\mathrm{KNO}_{3}\right)$, gave a better yield to the crops than chloride bond $\mathrm{K}(\mathrm{KCl})$. Incitecpivot (2005) stated that potassium nitrate $\left(\mathrm{KNO}_{3}\right)$ contained $13 \% \mathrm{~N}$ and $38.3 \% \mathrm{~K}_{2} \mathrm{O}$, this fertilizer was better for chloride sensitive crop like tobacco and could be applied through leaf spray. Moreover, the use of $\mathrm{KNO}_{3}$ was also beneficial as it could increase the availability of $\mathrm{N}$ nutrient in the soil. Gunadi (2009) stated that another K source like potassium sulphate $\left(\mathrm{K}_{2} \mathrm{SO}_{4}\right)$ could increase the potato starch content up to $9.2 \%$.

Mulching in the crop cultural technique is the quite precise method to reduce the loss of nutrient elements both through evaporation and washing. According to Sudarmadji and Rachman (2006); Sudadi et al. (2007), mulch is the remnants of crops or other materials given by the nature or artificial made as soil cover aim at certain purpose. The purpose of mulch is to protect soil surface from the attack of rainfall, erosion, and to keep soil moisture content, structure, fertility and to prevent the growth of weeds or wild grasses. Albert et al. (2010) reported that mulching have significantly influenced on $\mathrm{pH}$ and nutrient content.

$\mathrm{K}$ mineral has a high ability to retain water; on the other hand this mineral is also has difficulty to release the water. Kailan is a shallow root system crop and therefore this crop is very susceptible to drought and high leaching of nutrient elements. To be effective, K-fertilization should be combined with mulching to keep the soil moisture. Therefore, there is an interest in designing field experiment to evaluate the effect of rice hull mulching and $\mathrm{KNO}_{3}$ fertilization on kailan (B. oleraceae) growth and yield.

\section{MATERIALS AND METHODS}

\section{Study Site}

This study was carried out at the village of Simpang Kanan, the subdistrict of Sumberejo, the regency of Tanggamus, Lampung Province started in January up to March 2006. Material prepared were: seed of Kailan (Brasica oleraceae var Long Leaf), rice hull, manure of goat, and $\mathrm{KNO}_{3}$ fertilizer, Urea $(45 \% \mathrm{~N}), \mathrm{SP} 36\left(36 \% \mathrm{P}_{2} \mathrm{O}_{5}\right)$ and Curacron 500 EC (active ingredient: profenofos). Soil analysis was done in Soil Science Laboratory, Faculty of Agriculture, University of Lampung.

\section{Experimental Design}

Treatments were arranged in factorials in a completely randomized block design with 3 replications. The first factor was rice hull mulch which were with rice hull mulch $\left(10 \mathrm{Mg} \mathrm{ha}^{-1}\right.$ or 1 $\mathrm{kg} \mathrm{m}^{-2}$ ) and without rice hull mulch. The second factor was level of $\mathrm{KNO}_{3}$ application which were $150 \mathrm{~kg} \mathrm{ha}^{-1} ; 175 \mathrm{~kg} \mathrm{ha}^{-1} ; 200 \mathrm{~kg} \mathrm{ha}^{-1} ; 225 \mathrm{~kg} \mathrm{ha}^{-1}$ and $250 \mathrm{~kg} \mathrm{ha}^{-1}$.

\section{Land Preparation}

Land was cleared, ploughed and three seedbeds were formed. Each seedbed was divided into 10 plots. Each plot has the wide of $1 \mathrm{~m}^{2}$ with height of $30 \mathrm{~cm}$ and fertilized with goat manure with dosage of $30 \mathrm{Mg} \mathrm{ha}^{-1}$ or $3 \mathrm{~kg} \mathrm{~m}^{-2}$.

\section{Seed Preparation}

Before sowing the seed in each polybag, the seeds were first submerged for 30 minutes in water to accelerate sprouting. Seeds were germinated in a mixture of soil and manure (1:1) as a growing medium in the polybag. Every polybag was planted with two seeds of kailan.

\section{Planting}

Planting distance within the plot was a $25 \times$ $25 \mathrm{~cm}$ and the distance between plots was $30 \mathrm{~cm}$ with 16 seedlings. Before transplanting the seedlings, the half of the seedbed was treated with rice hull mulch and the other half was not treated. The thickness of the mulch was $5 \mathrm{~cm}$.

\section{Fertilizing}

Within an area of $30 \mathrm{~m}^{2}$, basic fertilizers were applied which were Urea $(45 \% \mathrm{~N})$ of $333 \mathrm{~g} 30$ $\mathrm{m}^{-2}\left(50 \mathrm{~kg} \mathrm{ha}^{-1} \mathrm{~N}\right)$, SP36 $\left(36 \% \mathrm{P}_{2} \mathrm{O}_{5}\right)$ of $834 \mathrm{~g} 30$ $\mathrm{m}^{-2}\left(100 \mathrm{~kg} \mathrm{ha}^{-1} \mathrm{P}_{2} \mathrm{O}_{5}\right)$. In addition to the inorganic fertilizers, an organic fertilizer was also applied, namely goat manure. The fertilizers above were used as a basic fertilizer. Application of fertilizer was done once at a planting time only.

Observation on growing components included variable of plant height, number of leaves, plant dry weight, plant fresh weight, the level of leaf greenness, leaf area and plant yields per plot. 


\section{Statistical Analysis}

Data were analyzed using ANOVA (Analysis of Variance) and continued by an orthogonal polynomial comparison test.

\section{RESULTS AND DISCUSSION}

\section{Soil Properties}

Table 1 presents results of soil analysis before and after $\mathrm{KNO}_{3}$ and rice hull mulch applications. The results showed the chemical properties of the soil that the soil was in the medium level of fertility, which indicated by a neutral soil $\mathrm{pH}$, a high $\mathrm{P}$ - total, a high $\mathrm{K}$ - total and a low N-total.

\section{Responses of Kailan}

The response of kailan to the application of rice hull mulch and $\mathrm{KNO}_{3}$ fertilizer on the growth component in the form of plant height, total number of leaves, leaves area, plant fresh weight, and plant dry weight. While the component of kailan production was plant yield in each plot which is

Table 1. Soil properties in the site of experiment before and after planting.

\begin{tabular}{lrr}
\hline Soil properties & $\begin{array}{l}\text { Before } \\
\text { planting }\end{array}$ & $\begin{array}{l}\text { After } \\
\text { planting }\end{array}$ \\
\hline $\mathrm{N}(\%)$ & 0.18 & 0.18 \\
$\mathrm{P} \mathrm{Bray-I}\left(\mathrm{mg} \mathrm{kg}^{-1}\right)$ & 174.99 & 174.13 \\
$\mathrm{~K}\left(\mathrm{cmol} \mathrm{kg}^{-1}\right)$ & 2.28 & 0.29 \\
$\mathrm{pH} \mathrm{H} \mathrm{H}_{2}(1: 2.5)$ & 6.03 & 5.89 \\
$\mathrm{pH} \mathrm{KCl}(1: 2.5)$ & 4.98 & 5.21 \\
\hline
\end{tabular}

presented in Table 2. The results showed that application of mulch did not affect plant height, total number leaves, plant fresh weight, plant dry weight and plant production in each plot.

Application of rice hull mulch influenced the increasing value of leaf greenness level and leaf area of the plant. The response of kailan on the application of $\mathrm{KNO}_{3}$ fertilizer did not depend on the application of mulch on all the variables (Table 2).

Result of the study showed that application of rice hull mulch could increase the leaf greenness level of $18.57 \%$ compared to the one without rice hull mulch. The increase in growth and yield of kailan was due to applications of rice hull mulch with thickness of $5 \mathrm{~cm}$ which could improve the environment of growing medium, as for example keeping the fluctuation of temperature and moisture of soil, providing shelter to the soil surface, as well as preventing weed infestation. This growing environment conditions will support root growth in term of root promulgation and root length in that the root can absorb nutrient properly, consequently it gave a better plant growth. This was reflected in the increase of leaf greenness level and leaf area.

As a comparison, according to Sudadi et al. (2007), application of rice straw mulch and manure could maintain soil moistures and could increase soil potassium availabity at the vegetative stage of soybeans. This was conformed with Lal (2000) and Ghosh et al. (2006) who stated that in generally application of mulch has function to control soil temperature, soil moisture and keep it being ideal for plant growth, beneficial for water availability as well as preventing weed infestation.

Table 2. Responses of kailan on application of rice hull mulch and $\mathrm{KNO}_{3}$ fertilizer.

\begin{tabular}{lccccccc}
\hline & \multicolumn{7}{c}{ Significances } \\
\cline { 2 - 8 } Comparison & $\begin{array}{c}\text { Plant height } \\
(\%)\end{array}$ & $\begin{array}{c}\text { Leaf } \\
\text { greenness } \\
\text { level }(\%)\end{array}$ & $\begin{array}{c}\text { Total } \\
\text { number of } \\
\text { leaves }(\%)\end{array}$ & $\begin{array}{c}\text { Leaf area } \\
(\%)\end{array}$ & $\begin{array}{c}\text { Plant fresh } \\
\text { weight }(\%)\end{array}$ & $\begin{array}{c}\text { Plant dry } \\
\text { weight }(\%)\end{array}$ & $\begin{array}{c}\text { Plant yield } \\
\mathrm{m}^{-2}(\%)\end{array}$ \\
\hline Mulching & & & & & & & \\
$\mathrm{A}_{1}: \mathrm{M}_{0}$ vs $\mathrm{M}_{1}$ & $1.46 \mathrm{~ns}$ & $6.10 * *$ & $5.15 \mathrm{~ns}$ & $18.57 * *$ & $4.91 \mathrm{~ns}$ & $4.37 \mathrm{~ns}$ & $2.76 \mathrm{~ns}$ \\
$\mathbf{K N O}_{3}$ dosages & & & & & & & \\
$\mathrm{A}_{2}:$ D-linier & $\mathrm{ns}$ & $\mathrm{ns}$ & $\mathrm{ns}$ & $*$ & $\mathrm{~ns}$ & $\mathrm{~ns}$ & $\mathrm{~ns}$ \\
$\mathrm{~A}_{3}: \mathrm{D}$-curve & $\mathrm{ns}$ & $\mathrm{ns}$ & $\mathrm{ns}$ & $\mathrm{ns}$ & $\mathrm{ns}$ & $\mathrm{ns}$ & $\mathrm{ns}$ \\
Interaction & & & & & & & \\
$\mathrm{A}_{4}: \mathrm{A}_{1} \times \mathrm{A}_{2}$ & $\mathrm{~ns}$ & $\mathrm{~ns}$ & $\mathrm{~ns}$ & $* *$ & $\mathrm{~ns}$ & $\mathrm{~ns}$ & $\mathrm{~ns}$ \\
$\mathrm{~A}_{5}: \mathrm{A}_{1} \times \mathrm{A}_{3}$ & $\mathrm{~ns}$ & $\mathrm{~ns}$ & $\mathrm{~ns}$ & $\mathrm{~ns}$ & $\mathrm{~ns}$ & $\mathrm{~ns}$ & $\mathrm{~ns}$ \\
\hline
\end{tabular}

Note: $\mathrm{M}_{0}=$ without mulch; $\mathrm{M}_{1}=$ with mulch; $* *=$ indicate a significant difference at $1 \%$ level; $*$ = indicate a significant difference at $5 \%$ level; and ns = indicate non significant difference at 1 and $5 \%$ level. 


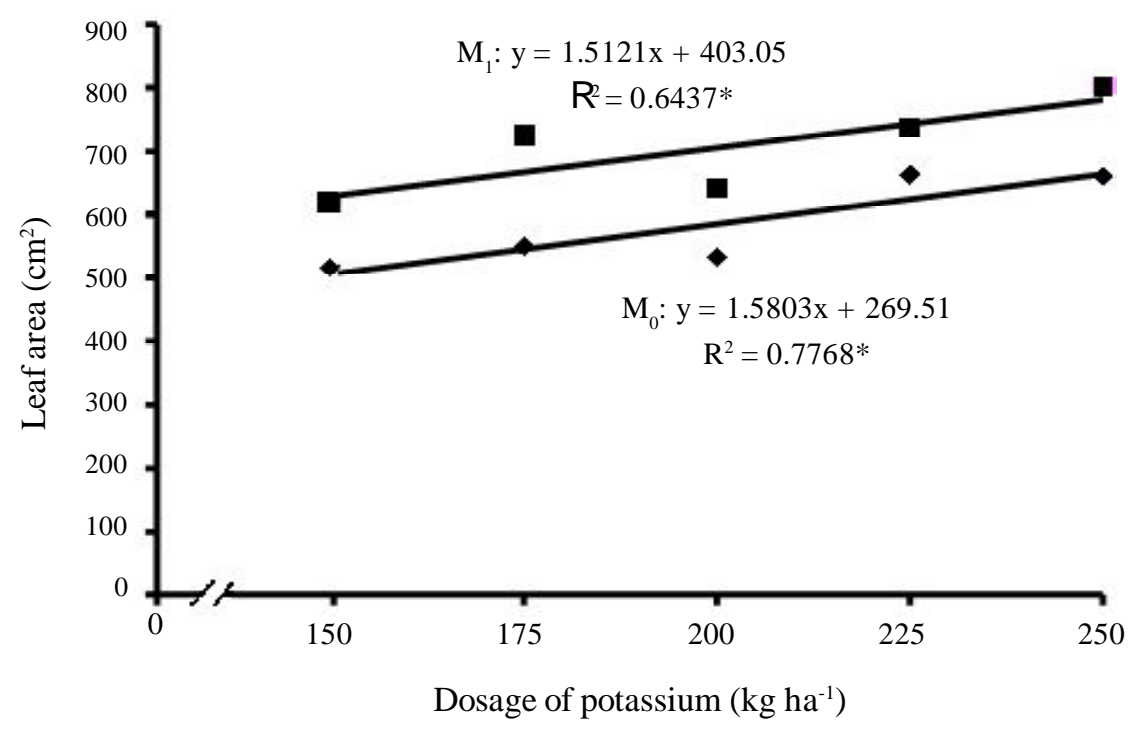

Figure 1. The relation between potassium dosage and leaf area on 40 days after planting. - = with mulch and $\bullet=$ without mulch.

Figure 1 showes application of mulch resulted the kailan leaf area of $119.89 \mathrm{~cm}^{2}, 18.57 \%$ more than the one without mulch. Application of mulch also increased the leaf area of kailan on the plot at $150 \mathrm{~kg} \mathrm{ha}^{-1} \mathrm{KNO}_{3}$ of $99.47 \mathrm{~cm}^{2}(17.47 \%)$ compared to the one without mulch.

Results of the study showed that the response of kailan on the application of potassium up to the dosage of $250 \mathrm{~kg} \mathrm{ha}^{-1} \mathrm{KNO}_{3}$ was just only on the leaf area variable and it still had a linear response. This indicated that the uptake of $\mathrm{KNO}_{3}$ at the vegetative phase of kailan was not maximal yet. The vegetative phase of kailan lasted very short time, it lasted 40 days after planting in the field. So that it was supposed that potassium was exploited to accelerate crown growth only during the vegetative stage. Potassium has a role in the photosynthesis as it directly increased growth and leaf area index, and also increased $\mathrm{CO}_{2}$ assimilation that required for carbohydrate synthesis. According to Incitecpivot (2005), generally the role of potassium was related to the physiological process, such as photosynthesis and respiration, carbohydrate and protein metabolism, enzyme activator, and help the closing and the opening of stomata processes as well as extensively the root growth.

Application of $\mathrm{KNO}_{3}$ fertilizers beside providing $39 \% \mathrm{~K}$, it was also contributed $\mathrm{N}$ element of $14 \%$ which indicated that an increase in $\mathrm{KNO}_{3}$ application would influence the availability of $\mathrm{N}$ in the soil (Oldham 2008). N source from $\mathrm{KNO}_{3}$ in the form of nitrate ion $\left(\mathrm{NO}_{3}^{-}\right)$can directly be used by the plant for its growth. This case was supported by the results of the study, that application of $\mathrm{KNO}_{3}$ up to $250 \mathrm{~kg} \mathrm{ha}^{-1}$ gave a contribution of $36.65 \mathrm{~kg}$ $\mathrm{ha}^{-1} \mathrm{NO}_{3}$ and $96.53 \mathrm{~kg} \mathrm{ha}^{-1}$ of $\mathrm{K}$ and it positively influenced on the leaf greenness level and leaf area of the plant. The leaf greenness level reflected the high amount of chlorophyll in the chloroplast.

\section{Leaf Area and Potassium}

Every addition of potassium dosage of $1 \mathrm{~kg}$ $\mathrm{KNO}_{3}$ ha $^{-1}$ could increase the leaf area of kailan of $1.58 \mathrm{~cm}^{2}$ without application of mulch, and of 1.51 $\mathrm{cm}^{2}$ with application of mulch (Figure 1).

The application of $\mathrm{KNO}_{3}$ as a compound (or complex) fertilizer was beneficial to the plant as $\mathrm{K}$ has a function as carbohydrate synthesis activator (Ruamrungsri et al. 1996) and the addition of $\mathrm{NO}_{3}$ could stimulate $\mathrm{NO}_{3}$ enzyme reductase which has a role in the absorption process of carbohydrate assimilation. However, $\mathrm{NO}_{3}$ absorption was also influenced by the presence of $\mathrm{K}$ in the soil solution. The increase in growth as influenced by $\mathrm{KNO}_{3}$ application could be seen from the increase in plant leaf area up to application of $250 \mathrm{~kg} \mathrm{ha}^{-1} \mathrm{KNO}_{3}$.

Application of manure of 30 ton ha ${ }^{-1}$ manure was enable to have a positive influence on the environment of planting media in that it has a low $\mathrm{N}$ - content of about $0.18 \%$. According to Sudadi et al. (2007), application of manure could increase the soil ability to hold water and therefore the soil moisture will be constant and it influenced the availability of $\mathrm{K}$ and other elements which were required by the plants. Another advantage of the manure/organic matter application was that the soil 
aeration became greater so that the uptake of $\mathrm{N}$ in the form of $\mathrm{NO}_{3}{ }^{-}$will be faster. Similar to Sarno (2009) in the case of caisim vegetable that application of chicken manure with dosage over 5 $\mathrm{Mg} \mathrm{ha}^{-1}$ could increase C-total, N-total, available-P and available- $\mathrm{K}$ and could lessen chemical fertilizer requirement.

Application of potassium had not increase all the observed growing variables except the leaf area of kailan. It was supposed that the high availability of the macro nutrients ( $\mathrm{K}$ and $\mathrm{P}$ ) in the soil as well as the influence of $\mathrm{N}$ that came from $\mathrm{KNO}_{3}$ fertilizer had been sufficient to support kailan vegetative growth. During the vegetative growing phase, the distribution of photosynthate accumulated in the leaf organ.

Results of the study showed that the influence of potassium application depended on the usage of rice hull mulch in the influencing the leaf area of kailan. There is a mutual dependent between rice hull mulch and applied potassium fertilizer. It was supposed that rice hull mulch could created a good environmental condition for the crop, so that increase nutrients uptake for the plant that reflected by the increase of leaf area variable.

\section{CONCLUSIONS}

A rice hull mulch application increased the growth and yield of kalian on the leaf greenness level and leaf area. Application of potassium was significant on the leaf area of the kailan. Dosage of potassium up to $250 \mathrm{~kg} \mathrm{ha}^{-1} \mathrm{KNO}_{3}$ still increased leaf area. The increase in leaf area was daffected by the application of potassium that in turn it depended on the application of rice hull mulch.

\section{REFERENCES}

Albert T, KKarp, M Starast and T Paal. 2010. The effect of mulching and pruning on the vegetative growth and yield of the half-high blueberry. Agron Res 8 (1): 759-769.

Aljabri M. 2007. Penetapan pupuk kalium berdasarkan kurva respon serta nisbah kalsium-kalium dan magnesium-kalium untuk padi sawah di Jawa Timur. J Akta Agrosia 10 (1): 23-31 (in Indonesian).

Erwiyono R, AA Sucahyo, Suyono and S Winarso. 2006. Keefektifan pemupukan kalium lewat daun terhadap pembungaan dan pembuahan tanaman kakao. Pelita Perkebunan 22 (1): 13-24 (in Indonesian).

Ghosh. PK, D Dayal, KK Bandyopadhyay and M Mohanty. 2006. Evaluation of straw and polythene mulch for enhancing productivity of irrigated summer groundnut. Field Crops Res 99: 76-86.
Gunadi N. 2009. Response of potato to potassium fertilizer sources and application methods in andisols of West Java. Indonesian J Agric Sci 10 (2): 65-72.

Havlin JL, JD Beaton, SL Tisdale and WL Nelson. 2005. Soil Fertility and Nutrient Management: An Introduction to Nutrient Management. $7^{\text {th }}$ Edition. Pearson/Prentice Hall. Upper Saddle River, NJ, 515 p.

Incitecpívot. 2005. Potassium Factsheet. Melbourne, Victoria. Available online at http:// www. Incitecpivot.com.au, 24 Februari 2009.

Jin JY. 1997. Soil potassium and potassium fertilizer use in Nothern China. Better Crops Inter 11(1): 16-17.

Labosky C and L Bundy. 2005. Prioritizing Potassium Fertilizar Applications. Extension Soil Scientists. Department of Soil Science. Available online at http://www.uwex.edu/ces/ag/teams/grains/ documents/Prioritizing-K-Apps2005.pdf, 9 October 2008.

Lal R. 2000. Mulching effects on soil physical quality of an alfisol in western Nigeria. Land Degrad Dev 11 (4): 383-392.

Mallarino AP and B Havlovic. 2008. Phosphorus and Potassium Fertilizer Placement for Corn and Soybeans Managed with No-till and Chisel-Disk Tillage. Available online at http:// www.agronext.iastate.edu/soilfertility, 24 Februari 2009.

Mapegau. 2001. Pengaruh pupuk kalium dan kadar air tanah tersedia terhadap serapan hara pada tanaman jagung kultivar Arjuna. [Bachelor Script]. Jurusan BDP, Fakultas Pertanian Jambi (in Indonesian).

Nursyamsi D, K Idris, S Sabiham, DA Rachim and A. Sofyan. 2006. Pengaruh asam oksalat, $\mathrm{Na}^{+}, \mathrm{NH}^{+}$ dan $\mathrm{Fe}^{3+}$ terhadap ketersediaan $\mathrm{K}$ tanah, Serapan $\mathrm{N}, \mathrm{P}$ dan $\mathrm{K}$ tanaman, serta produksi jagung pada tanah-tanah yang didominasi smektit. J Tanah Iklim 28: 69-82 (in Indonesian).

Oldham L. 2008. Potassium in Mississipi Soils. Mississipi State University Extention Services, 4 p.

Ruamrungsri S, T Ohyama and T Ikarashi. 1996. Nutrients, free amino acids, and sugar contents in Narcissus root effected by N, P, K deficiency during winter. Soil Sci Plant Nutr 42 (4): 765-771.

Sarno. 2009. Pengaruh kombinasi NPK and Pupuk kandang terhadap sifat tanah dan pertumbuhan serta produksi tanaman Caisim. J Tanah Trop 14 (3): 211219 (in Indonesian).

Sudadi YN, Hidayati and Sumani. 2007. Ketersediaan $\mathrm{K}$ dan hasil kedelai (Glycine max L. Cerril) pada tanah vertisol yang diberi mulsa dan pupuk kandang. J I Tanah Lingk 7 (1): 8-12 (in Indonesian).

Sudarmadji T and G Rachman. 2006. Percobaan penggunaan mulsa alang-alang untuk pengendalian erosi tanah pada lahan kritis dengan kelerengan yang beragam.http://72.14.235.104/search?q= cache:55jswSLvQQoJ:unmul.ac.id/dat/pub/frontir/ triyono.pdf+mulsa\&hl=id\&, 20 February 2007. 
Summers R. 2001. Potassium for high rainfall pastures. Departement of Agriculture, Western Australia. Available online at www.soilquality.org.auPotassium-web.pdf, 24 Februari 2009.
Yamaguchi M. 1983. World Vegetables:Principle, Production and Nutritive Values. Van Nostransnd Reinhold Co. New York. 416 pp. 